\title{
Determining the Training Needs of Teachers in Ethical Use of Information Technologies*
}

\section{Bilişim Teknolojilerinin Etik Kullanımına İlişkin Öğretmenlerin Eğitim İhtiyaçlarının Belirlenmesi}

\author{
Emre BAYSAN ${ }^{* *}$
}

\author{
Şaban ÇETÍN
}

\begin{abstract}
Received: 24 February 2021
Research Article

Accepted: 18 June 2021

ABSTRACT: In this study, the training needs of teachers regarding the ethical use of information technologies were examined. The training needs levels of teachers and the significant differentiations of training needs according to gender, teaching level, professional seniority, branch, and education degree were investigated. In this study, the discrepancy view approach and normative need type were used. The data were collected via "The Scale of Ethical Use of Information Technologies in Education" developed by Baysan and Çetin (2019). The survey method was applied. The research was carried out with 745 teachers working in public schools in Afyonkarahisar, Turkey. The sample group was determined by stratification method and simple random sampling method. Schools were stratified as primary school, secondary school, divinity secondary school and high school. A certain number of schools from each stratum were determined by lot, and it was aimed to reach all teachers in the specified schools. More than half of the participants were female with a rate of 55.5\%. Data were collected from teachers working in five different main branches. According to the results, $22.8 \%$ of teachers need ethical training in the Stalking sub-dimension, $14.5 \%$ in the Communication sub-dimension, and $9.4 \%$ in the Confidence and Material sub-dimension. In the Privacy and Accessibility sub-dimensions, nearly $1 \%$ of teachers need ethical training. Regarding the ethical use of information technologies, there were significant differences in some sub-dimensions according to some independent variables. Results show that teachers need less ethical training than expected.
\end{abstract}

Keywords: Ethics, Information Technologies (IT), Teacher.

ÖZ: Bu çalışmada öğretmenlerin bilişim teknolojilerinin etik kullanımına ilişkin eğitim ihtiyaçlarının belirlenmesi amaçlanmıştır. Bu amaç çerçevesinde öğretmenlerin bilişim teknolojilerinin etik kullanımına ilişsin eğitim ihtiyaçları düzeyleri ve eğitim ihtiyaçlarının cinsiyet, öğretim kademesi, kıdem, branş ve eğitim düzeylerine göre farklılaşması durumu araştırılmışır. Çalışma kapsamında farklar yaklaşımı ve normatif ihtiyaç türü kullanılmıştır. Araştırmada betimsel araştırmalardan tarama modeli tercih edilmiştir. Veriler, Baysan ve Çetin (2019) tarafindan geliştirilen "Eğitimde Bilişim Teknolojilerinin Etik Kullanımı Ölçeği” ile toplanmış, elde edilen veriler istatistik yazılımları aracılığıyla analiz edilmiştir. Araştırma Afyonkarahisar il merkezinde devlet okullarında görev yapan 745 öğretmen ile gerçekleştirilmiştir. Örneklem grubu tabakalama ve basit tesadüfi yöntemle belirlenmiştir. Okullar ilkokul, ortaokul, imam hatip ortaokulu ve lise olmak üzere tabakalanmıştır. Her bir tabakadan kura ile belirlenen okullardaki tüm öğretmenlere ulaşılması hedeflenmiştir. Katılımcıların yarıdan fazlası \% 55.5 oran ile kadın öğretmenlerden oluşmaktadır. Beş ana branşta görev yapan öğretmenlerden veriler toplanmıştır. Analiz sonuçlarına göre öğretmenlerin \% 22.8'i Habersiz Takip, \% 14.5'i İletişim, \% 9.4'ü Güven ve Materyal alt boyutlarında etik eğitime ihtiyaç duyduğu söylenebilir. Gizlilik ve Erişebilirlik ismi verilen alt boyutlarda eğitim ihtiyacı öğretmenlerin yaklaşık \% 1'lik bir kısmına gerekmektedir. Bilişim teknolojilerinin etik kullanımı konusunda öğretmenlerin bazı bağımsız değişkenlere göre alt boyutlarda anlamlı farklılıkları olduğu tespit edilmiştir. Sonuçlar, öğretmenlerin beklenenden daha az etik eğitime ihtiyaç duyduğunu göstermektedir.

Anahtar kelimeler: Etik, Bilişim Teknolojileri (BT), Öğretmen.

\footnotetext{
* This article was produced from the doctoral dissertation, namely "Determining the training needs of teachers in ethical use of information technologies" submitted to Gazi University Institute of Educational Sciences.

** Corresponding Author: Dr., Afyon Kocatepe University, Afyonkarahisar, Turkey, emrebaysan@aku.edu.tr, https://orcid.org/0000-0002-3629-2880

*** Prof. Dr., Gazi University, Ankara, Turkey, scetin@gazi.edu.tr, https://orcid.org/0000-0002-4319-5667
}

Citation Information

Baysan, E., \& Çetin, Ş. (2021). Determining the training needs of teachers in ethical use of information technologies. Kuramsal Eğitimbilim Dergisi [Journal of Theoretical Educational Science], 14(3), 476-497. 
Today, with the development of electronic devices and the spread of the internet, it is observed that information and communication technologies offer new opportunities to people as never before. It is useful to use the technology in educational environments in terms of reducing learning time, providing simultaneous, asynchronous, online and offline environments, providing distance learning opportunities and individualized educational materials, branching subjects according to needs, and providing opportunities for disabled students (Çiftçi, 2009, p. 20). Furthermore, technology usage in the classroom contributes to positive attitudes towards learning, collaborative learning behaviors, acquisition of new learning methods, and communication skills (Kozma, 2003).

The use of technology in the classroom also raises ethical issues. Teachers are in a unique position to show students how to use technology correctly. Teachers should teach students the possible dangers of not obeying ethical rules while using the internet and guide them in using the internet at an age-appropriate level. Teachers are expected to be role models for students in terms of the ethical use of technology because students learn from examples (Akcay, 2008).

Students' digital literacy has become as important as reading and writing. Putting ethical values into practice is now among the characteristics of the new generation (Moffat, 2013). The Turkish Ministry of National Education (MoNE) also published current curriculums on the official website. There is a unit titled "Ethics and Safety" in the Information Technologies and Software course taught in primary and secondary schools (MoNE, 2018a). The subject of Ethics, Security, and Society is included in the curriculum of the Computer Science course in secondary education (MoNE, 2018b). The Council of Higher Education (CoHE) has recommended "Ethics and Morals in Education" course to all departments in Teacher Training Undergraduate Programs (CoHE, 2018). The ethical use of information technologies is important not only for teachers who teach this course but also for teachers in other branches who communicate and interact with students. Information ethics is not only a subject to be taught to students, but it also refers to the rules that all stakeholders must obey. In this context, it is expected that students, teachers, parents, and administrators are also conscious of these rules.

NASDTEC, which is dedicated to providing leadership and support to educators, released a model code of ethics. The association announced the responsibilities to the profession, students, the school community, professional competence, and ethical use of technology. According to the text, professional teachers should use technology and social media responsibly and accountably for teaching and learning purposes. They should closely follow the current trends of technology used in education. They should be able to encourage colleagues, school staff, parents, and community members to implement useful technologies such as web 2.0 tools. Additionally, they should know how to access, certify, and use information and explain to students and educators how to recognize and prevent plagiarism. Finally, they should be educated to keep their personal and professional lives separate and act prudently in protecting virtual profiles (Mcee, 2020).

In the $19^{\text {th }}$ National Education Consultation, under the heading of increasing the quality of teachers, there is a recommendation that "As in every profession, the ethical codes and professional standards of the teaching profession should be established 
immediately and shared with the relevant parties. These standards are strategically important in increasing the social reputation of the teaching profession" (MoNE, 2014, 2.1.6./39). Academic studies are expected, as stated above. Knowing, accepting, and applying ethical values means that teachers also know the most appropriate behavior in their professional lives (Çörez, 2016, p. 443; Muir \& Reeder, 1929, p. 69). Ethical rules show that the profession has a reputation. Professional ethical rules in the field of instructional technology are intended to protect the rights of the field itself and those working in that field (Çörez, 2016, p. 443; Yeaman et al., 2008, p. 295).

How ethically teachers use hardware, software, and social media tools should be questioned. In cases where ethical values are not followed, the training needs of teachers have come to light. In this respect, the status of teachers in ethical use of information technologies should be revealed. Various in-service and out-of-service activities should be developed in line with the training needs. Based on this, conducting research for the training needs of teachers regarding the ethical use of information technologies is necessary.

The general purpose of this research was to determine the training needs of teachers regarding the ethical use of information technologies. For this purpose, the following questions were sought:

1. What are the training needs of teachers regarding the ethical use of information technologies?

2. Do the training needs of teachers differ significantly according to their gender, teaching level, professional seniority, branches, and education degree?

It is hoped that this study will provide significant contributions to the educational activities for teachers to achieve their ethical use of information technologies.

\section{Theoretical Framework and Literature}

Ethics, derived from ethos in ancient Greek, expresses the relationship between humans and other beings according to certain norms, principles, rules, and values (Cevizci, 2012, pp. 2-3). Ethics is the branch of philosophy that deals with questions about how we should live, what right and wrong is, how to determine good and bad, and what we should and should not do (Buckinghan, 2012, p. 341). Informatics Ethics is a philosophy branch that examines the behaviors of service providers and users in the field of informatics (TBD, 2010). It is an applied ethics field that examines the behaviors of individuals in the informatics environment (Leymun, 2018). Information technologies are all tools and equipments used in informatics (TDK-BT, 2020). These cover all technologies, including computers used to collect, process, and store information, transmit it from one place to another via networks, and present it to users. Information technologies are all kinds of visual, audio or printed tools that enable forming information and accessing it.

Education is the process of creating a deliberate change in an individual's behaviors through his own life. It is the sequence of changes in the desired direction in a person's behaviors through interaction with other people and their environment (Demirel \& Kaya, 2015, p. 6). After determining the training needs of teachers for IT 
ethics, a new phase needs to be handled, which is to educate those who lack their professional competence in ethical care.

Need is a requirement, strong desire, poverty, and absence (TDK-i, 2020). Witkin and Altschuld (1995, p. 9) defined need as a gap. They explained this gap as the difference between the current situation (What is it?) and the state that should be (What should be?). Training need is the difference between the competencies required by a job and the competencies of the personnel. It is also defined as the difference between the competencies required for future work and the competencies for the current job. This difference indicates the competencies to be gained to the staff and the need for inservice training (Taymaz, 1997, pp. 25-26).

Witkin and Altschuld (1995, pp. 10-12) examined the concept of need at three levels. At the first level, there are people who receive services such as students. At the second level, there are those who provide services such as teachers. At the third level, there are resources and solutions such as technology. Witkin and Altschuld (1995, p. 15) stated that needs analysis could be done in three phases. These are phases of exploration, data gathering, and utilization.

Burton and Merrill (1991, pp. 17-43) determined that there are six types of needs as a result of their evaluation. These are normative needs, felt needs, expressed needs (or demand), comparative needs, anticipated needs (or future needs), and criticalincidents needs. In normative needs, it occurs when a person cannot meet the specified standard. Stufflebeam et al. (1985, pp. 3-8) identified four different needs assessment approaches. These are discrepancy, democratic, analytical approach, and diagnostic view. Discrepancy view is the need arising from the gap between desired performance and observed performance. It is necessary to have a norm and criterion for this needs analysis. Within the scope of this study, the normative need type and discrepancy view were used. The gap between the desired situation and the observed situation shows the training needs of the teachers.

Sivin and Bialo (1992, pp. 11-12) presented an overview of the ethical values of students, teachers, administrators, and policymakers on education. They examined some case events that occur among teachers and students. For example, teachers in a primary school have distributed cracked copies of the software to the students. In a secondary school, students have been encouraged to communicate via e-mails. After a while, a student has started to write stories with obscene content as e-mail to his friends. A high school student has shared stolen phone access codes over a class communication forum. They mentioned that mostly students and in some cases educators need guidance on the legal and ethical values of technology use as a result.

Tanrikulu (2019) studied to find out how school children learn cyberbullying. Articles in the subject areas were reviewed. Three main reasons have been identified. These are home related ones, school related ones and technology related ones. Schools are common places where children socialize. School children learn from peers and adults. As a finding, it has revealed that school children in all grades cyberbully others. The indifference of teachers or principals also has been found out another reason for cyberbullying perpetration.

Dedeoğlu (2006) addressed the increasing ethical problems due to the influence of information technologies. The accuracy of the information, private life, privacy, 
personal rights, computer crimes, intellectual property rights, unemployment, health problems, social relations, home offices, family related issues, virtual environment, virtual relationships, numerical division, artificial intelligence, and social interest are some of the main problem areas.

Çelen and Seferoğlu (2016) examined local and foreign literature on unethical behavior in the use of information and communication technologies. Results of these reviews reveal that facilities provided by technology can encourage a modest person in social life to act unethically and commit crimes in the cyber world. Social norms, gender, parental education status, age, personal values, moral judgement, social values, and moral responsibility were found to be effective in the ethical and legal use of information and communication technologies. According to the review results, universities were the most studied level with $68 \%$ in total as the participant group. There is no study with high school and very low with primary level.

Levent and Kinık (2017) examined postgraduate theses on ethics in the education field in Turkey. In these theses, mostly school managers $(\% 44,6)$, teachers $(\% 16,5)$, candidate teachers and students were studied as participating groups. The majority of these studies were made at the Master's degree level.

Fidan (2016) examined the Information Technologies and Software Course taught at the secondary school level according to the dimensions of informatics ethics. According to the results, there is no outcome in the book regarding cyberbullying and cybercrime. Copyrights have been mentioned, but concepts such as intellectual property and patent infringement are not explicitly included. Communication and social impact are left superficial. The main recommendation of the researcher is to provide education at an early age in order to minimize the problems that may be experienced regarding ethics.

Sarıkoç (2018) investigated teachers' unethical computer use behaviors. According to the results, unethical computer usage behaviors do not change according to the branch. It varies according to gender, age, and professional seniority. Males, elders, and those with more years of service show more unethical behavior than others. The most interesting result obtained is that those who receive informatics ethics training act more unethically than those who do not.

Mccannon and Crews (2000) evaluated the technology education needs of primary school teachers. Computers and technology are widely used in high school and middle school as well as in primary schools. However, technologies in school are used for administrative purposes rather than educational processes. Personnel development courses have been mostly for administrators and limited to teaching word processing software so far. Researchers suggested topics such as the use of the World Wide Web and CD-ROMs, learning presentation software, and conducting research with computers for teachers.

Akçadağ (2010) investigated the training needs of teachers regarding methods, techniques, and measurement and evaluation techniques in the primary education curriculum. According to the results, the teachers stated that they were in need of training in methods and techniques of drama, concept map, fishbone, mind map, providing learning environments, preparing a learning environment according to intelligence fields, product file, checklist, and project. 
$\mathrm{Hu}$ (2010) focused on the training needs of early childhood teachers in China in her study. The topics "Directing the behaviors of children", "Helping students to solve their own problems in the face of what is happening", and "Teaching self-control" were the most frequently needed situations by teachers.

Vladimirovna et al. (2016) investigated teacher competence for preventing pupils' deviant behaviors in ICT. Teachers would need training if they lack competence. Anti-social, immoral, illegal criminal activities, script-kidding, cybersex, trolling, flooding, flaming with ICT are some of deviant behaviors. In order to make prospective teachers competent, they should be trained to diagnose the bizarre behavior of pupils. In addition, they have to be aware of information security and the impacts of ICT on the mental, emotional and physical health and also ethical, legal, and moral use of ICT.

Mâta et al. (2020) developed a scale to measure the attitude of university teachers towards the ethical use of ICT. The scale consists of 13 items and 4 factors: cognitive needs, cognitive constraints, behavioral ICT Use, and behavioral data management. There are some traditional items in the scale, such as "Distributing information in online environment without indicating the source violates ethical rules for the use of IT. The teacher must check whether or not the students use information technology ethically. An unlicensed educational software can be used in current educational activities. Phrases can be processed from an online source, in research work, without mentioning the source."

Novella-García and Cloquell-Lozano (2021) made a content analysis for gathering data about ethical dimension of digital competence in prospective teacher training subjects in Spain. 118 study plans were reviewed. The results showed that digital competence was included in nearly three-fourths of the plans, but the ethical dimension was included only in one-fourths of the plans. This means that prospective teachers currently receive little training in digital ethics than digital competence training.

Baydar's (2021) study aims to determine and compare the relationship between cyberloafing and ethical behaviors of teachers' and school administrators'. The study was carried out within Istanbul province, and the data was collected electronically via an ethical behaviors scale. According to the results, school administrators and teachers' perceptions of ethical behaviors were very high and their perceptions of cyberloafing were low.

In the training needs studies in which teachers are the subject, the training needs regarding professional competence, method, technique, measurement, evaluation, general culture, field knowledge, vocational knowledge, constructivist approach, early childhood, and the situation of gifted people have been investigated. However, the original aspect of this study is that the training needs of teachers regarding the ethical use of information technologies have not been investigated.

\section{Method}

\section{Research Design}

In the study, the survey research design from descriptive researches was employed to determine the educational needs of teachers regarding the ethical use of information technologies. In descriptive research, a situation is defined as completely 
and carefully as possible. Studies aimed at collecting data to determine certain characteristics of a group are called survey research (Fraenkel et al., 2012, p. 12, 15). Survey studies provide a quantitative description of trends, attitudes, and views across the universe through studies conducted on a sample (Creswell, 2017, p. 155). The university ethics committee report and the provincial governor permission were taken to make this research.

\section{Participants}

The entire population of the research was the teachers working in public schools in Afyonkarahisar province. The sample group was determined from this population. The schools were stratified as primary school, secondary school, divinity secondary school and high school. The schools in the city center were determined and appointed to relevant stratum. A certain number of schools were randomly selected from each stratum. It was aimed to reach all teachers in the selected schools.

There are 8.713 teachers working in 838 educational institutions in Afyonkarahisar province (Afyon MEM, 2019). Twenty-five primary schools, 18 secondary schools, eight divinity secondary schools, eight high schools were selected by drawing lots. Teachers working in each selected school are included in the sample group.

A total of 745 teachers were reached within the scope of the study. After the missing data were excluded, the analyses were made with 641 data. The data collected from the participants were used only within the framework of this research and were not subject to other studies and were not made available to third parties. The distributions of the participants according to their demographic values are given in Table 1 in terms of frequency and percentage.

Table 1

Distribution of Participants According to Demographic Data

\begin{tabular}{lcc}
\hline Gender & $n$ & $\%$ \\
\hline Female & 356 & 55.5 \\
Male & 285 & 44.5 \\
\hline Teaching Level & $n$ & $\%$ \\
\hline Primary school & 235 & 36.7 \\
Secondary school & 250 & 39 \\
High school & 156 & 24.3 \\
\hline Professional Seniority & $n$ & $\%$ \\
\hline 0-5 years & 81 & 12.6 \\
6-10 years & 160 & 25.0 \\
11-15 years & 143 & 22.3 \\
16-20 years & 124 & 19.3 \\
21++ years & 133 & 20.8 \\
\hline
\end{tabular}




\begin{tabular}{lcc}
\hline Main Branch & $n$ & $\%$ \\
\hline Elementary & 230 & 35.9 \\
Science \& Math & 108 & 16.9 \\
Social Sciences \& Language & 188 & 29.3 \\
Fine Arts & 49 & 7.6 \\
Vocational & 66 & 10.3 \\
\hline Education Degree* & $n$ & $\%$ \\
\hline Under Graduate & 561 & 87.5 \\
Master (MS) & 75 & 11.7 \\
Doctorate (PhD, EdD) & 2 & .3 \\
Other & 3 & .5 \\
\hline Total & 641 & 100
\end{tabular}

* MS: Master of Science, PhD: Doctor of Philosophy, EdD: Doctor of Education

According to the data in Table 1, 356 of the 641 teachers participating in the study are women and 285 are men. Proportionally, 55.5\% of the participants are women and $44.5 \%$ are men. 235 of the 641 teachers participating in the study are in primary school, 250 are in secondary school, and 156 are in high school. Proportionally, 39\% of the participants work in secondary schools, $36.7 \%$ in primary schools, and $24.3 \%$ in high schools. 81 of the 641 teachers participating in the study work in their first five years, 160 in the second five years, 143 in the third five years, 124 in the fourth five years, and 133 in the fifth five years and more. The group with the highest participation is the teachers who worked for the second five years with $25 \%$. The group with the least participation is the teachers who worked for the first five years with $12.6 \%$.

Participant teachers are mostly located in the Elementary branch, secondly in the Social Sciences \& Language branch, and thirdly in the Science \& Math branch. The least participation was from Fine Arts and Vocational branches. In the main branch of the Elementary, there are "Primary Education", "Special Education Teaching", and "Preschool Teaching". In the main branch of the Science \& Math, there are "Mathematics", "Science and Technology", and "Physics, Chemistry, Biology Teaching". In the main branch of the Social Sciences \& Language, there are "Turkish", "Turkish Language and Literature", "Foreign Language", "Religious Culture and Ethics", "Social Sciences", and "History, Geography, Philosophy Teaching". In the main branch of the Fine Arts, there are "Visual Arts", "Music, Physical Education Teaching" and "Technology Design Teaching". In the main branch of the Vocational, there are "Guidance and Consulting", "Information Technologies", "Workshop, Lab., Vocational and Field Courses Teaching", and "Divinity Vocational Courses Teaching".

According to the data in the table, 561 of the 641 teachers participating in the study are undergraduate, 75 are master and 2 are doctorate graduates. Three are who are not graduates of university. Proportionally, $87.5 \%$ of the participants are undergraduates and $12 \%$ are master and doctorate education graduates. 


\section{Data Collection Tool}

The scale used in the study was developed by Baysan and Çetin (2019). The item pool of the scale was formed from the items of ethical scales in the literature and interviews with teachers. The first part of the scale consisted of demographic information such as gender, teaching level, branch, educational degree, and professional seniority. The second part consisted of scale items with 5-Likert type options. A draft form with 56 items was created and an exploratory factor analysis was made from the pilot application.

As a result of exploratory factor analysis, five sub-dimensions were determined with $54 \%$ of the total variance. Sub-dimensions are namely, Privacy, Communication, Stalking, Accessibility, Confidence and Material. Cronbach Alpha internal consistency coefficients of the sub-dimensions were .81, .79, .74, .65 and .58, respectively. Cronbach's alpha internal consistency coefficients for the whole scale is .85 . The five sub-dimensions consist of 8, 4, 3, 3, and 5 items, respectively. The KMO (Kaiser Meyer Olkin) value of the 23-item final form of the scale was .83 and Bartlett's test of sphericity was significant. According to the confirmatory factor analysis results, model fit indexes were good and acceptable and the scale was a valid and reliable measurement tool. Due to low level correlation coefficients, participants would not be given a total score from the scale; sub-dimensions should be evaluated separately.

\section{Data Collection and Analysis}

With the scale of ethical use of information technologies in education, quantitative data were collected, and the data were analyzed through statistical software. In order to collect data in schools, the approval of the Governorship and the ethics committee report were received. The researcher applied the scale on a voluntary basis by reaching the schools one by one without disrupting education and training. Answers to research questions were sought with the obtained data.

The scale consists of demographic information of the participants and question items. Before the statistical analysis, the missing data analyses were made over the collected data. Leaving one of the question items missing may require excluding that participant from the study. During the research, maximum effort was made to fill them in the scale forms completely, and the forms with incomplete information that could not be compensated were removed from the research.

In order to determine the normality of the data set, central tendency measures, skewness and kurtosis coefficients of the distribution, Kolmogorov-Smirnov and Shapiro-Wilk test results, frequency distributions, normal quantile-quantile plot, and detrended normal Q-Q plot graphs were examined. According to these results, the data were not distributed normally, so non-parametric tests should be used in the analysis of the data.

The demographic information of the participants were given in tables under Participants heading. According to the responses of the participants to the scale, training needs for each sub-dimension were also given in tables under the Findings heading. Mann Whitney-U and Kruskal-Wallis tests were conducted to determine whether the participants' scores made a significant difference according to independent variables on a sub-dimension basis. 


\section{Results}

This section includes missing data analysis, normality tests, training needs of teachers regarding sub-dimension and significance tests according to independent variables. If categorical entries were not filled fully by the participants, these forms were not included in the data set. Then data set was checked whether it is randomly distributed or not. According to the EM estimated statistical analysis result, $p<.05$; the data were not randomly distributed, so missing data could not be assigned. So the forms containing the missing items were also removed. Although data were collected from a total of 745 participants at the beginning, then the analyses were made with 641 data.

The normality of the data was checked with central tendency measures, the skewness and kurtosis coefficients, Kolmogorov-Smirnov and Shapiro-Wilk tests, the frequency distributions, the normal Quantile-Quantile chart and Detrended Normal Q-Q Plot graphics. The mean, median, and peak values in the data set should be close to each other in normal data distribution. The data were close to each other for five factors. These results showed that the data were normally distributed. When the skewness or kurtosis is divided by standard error, and the result is between $-1,96$ and $+1,96$, then the data distribution is normal (Can, 2016, pp. 84-90). But unfortunately, the values were between -31.608 and 76.082. The desired value ranges were not captured. If the normality values are significant in Kolmogorov-Smirnov and Shapiro-Wilk tests, the data are not distributed normally. The $p$ value of all sub-dimensions for both tests was below .05. The values are significant and the data were not distributed normally. The normality of the data was checked according to the frequency distributions. A symmetrical bell curve emerges when the peaks of the bars in the graph are combined in the data exhibiting normal distribution. The frequency distributions of the data for five sub-dimensions had an increasing trend from left to right. So the data was not distributed normally. The normality of the data was checked according to the normal Quantile-Quantile chart and Detrended Normal Q-Q Plot graphics. As a result of the above tests performed for this study, the data for all five sub-dimensions in the scale were not normally distributed, so non-parametric tests were used in the analysis of the data. 


\section{Teachers' Training Needs regarding the Ethical Use of IT}

The participants were given mean scores according to sub-dimensions. It was accepted that those who perform completely unethical, unethical, and moderate ethical behavior need training. The numbers and percentages of the participants in the privacy sub-dimension corresponding to the value ranges are given in Table 2.

Table 2

The Participants' Training Needs According to Privacy Sub-dimension

\begin{tabular}{cccc}
\hline Mean Ranges & Status & $n$ & $\%$ \\
\hline $1.0-1.8$ & Completely unethical & 1 & .16 \\
$1.8-2.6$ & Unethical & 2 & .31 \\
$2.6-3.4$ & Moderate ethical & 3 & .47 \\
$3.4-4.2$ & Ethical & 45 & 7.02 \\
$4.2-5.0$ & Very ethical & 590 & 92.04 \\
\hline Total & & 641 & 100
\end{tabular}

According to the data in Table 2, one teacher exhibits completely unethical, and two teachers exhibit unethical while three teachers exhibit moderate ethical behavior. In this case, it was seen that $1 \%$ of the participant teachers need training in the context of the privacy sub-dimension. The numbers and percentages of the participants in the communication sub-dimension corresponding to the value ranges are given in Table 3.

Table 3

The Participants' Training Needs According to Communication Sub-dimension

\begin{tabular}{cccc}
\hline Mean Ranges & Status & $n$ & $\%$ \\
\hline $1.0-1.8$ & Completely unethical & 9 & 1.4 \\
$1.8-2.6$ & Unethical & 18 & 2.8 \\
$2.6-3.4$ & Moderate ethical & 66 & 10.3 \\
$3.4-4.2$ & Ethical & 157 & 24.5 \\
$4.2-5.0$ & Very ethical & 391 & 61.0 \\
\hline Total & & 641 & 100 \\
\hline
\end{tabular}

According to the data in Table 3, nine teachers exhibit completely unethical, 18 teachers exhibit unethical while 66 teachers exhibit moderate ethical behavior. In this case, it was seen that $14.5 \%$ of the participant teachers need training in the context of the communication sub-dimension. The numbers and percentages of participants in the stalking sub-dimension corresponding to the value ranges are given in Table 4. 
Table 4

The Participants' Training Needs According to Stalking Sub-dimension

\begin{tabular}{cccc}
\hline Mean Ranges & Status & $n$ & $\%$ \\
$1.0-1.8$ & Completely unethical & 10 & 1.6 \\
$1.8-2.6$ & Unethical & 28 & 4.4 \\
$2.6-3.4$ & Moderate ethical & 108 & 16.8 \\
$3.4-4.2$ & Ethical & 147 & 22.9 \\
$4.2-5.0$ & Very ethical & 348 & 54.3 \\
\hline Total & & 641 & 100 \\
\hline
\end{tabular}

According to the data in Table 4, 10 teachers exhibit completely unethical, and 28 teachers exhibit unethical while 108 teachers exhibit moderate ethical behavior. In this case, it was seen that $22.8 \%$ of the participant teachers need training in the context of the stalking sub-dimension. The numbers and percentages of participants in the accessibility sub-dimension corresponding to the value ranges are given in Table 5.

Table 5

The Participants' Training Needs According to Accessibility Sub-dimension

\begin{tabular}{cccc}
\hline Mean Ranges & Status & $n$ & $\%$ \\
\hline $1.0-1.8$ & Completely unethical & 1 & .16 \\
$1.8-2.6$ & Unethical & 0 & 0 \\
$2.6-3.4$ & Moderate ethical & 6 & .94 \\
$3.4-4.2$ & Ethical & 48 & 7.5 \\
$4.2-5.0$ & Very ethical & 586 & 91.4 \\
\hline Total & & 641 & 100
\end{tabular}

According to the data in Table 5, one teacher exhibits completely unethical, and no teacher exhibits unethical while six teachers exhibit moderate ethical behavior. In this case, it was seen that $1.1 \%$ of the participant teachers need training in the context of the accessibility sub-dimension. The numbers and percentages of participants in the confidence and material sub-dimension corresponding to the value ranges are given in Table 6. 
Table 6

The Participants' Training Needs According to Confidence and Material Sub-dimension

\begin{tabular}{cccc}
\hline Mean Ranges & Status & $n$ & $\%$ \\
\hline $1.0-1.8$ & Completely unethical & 0 & 0 \\
$1.8-2.6$ & Unethical & 6 & .94 \\
$2.6-3.4$ & Moderate ethical & 54 & 8.42 \\
$3.4-4.2$ & Ethical & 181 & 28.2 \\
$4.2-5.0$ & Very ethical & 400 & 62.4 \\
\hline Total & & 641 & 100
\end{tabular}

According to the data in Table 6, no teacher exhibits completely unethical, and six teachers exhibit unethical while 54 teachers exhibit moderate ethical behavior. In this case, it was seen that $9.4 \%$ of the participant teachers needed training in the context of the confidence and material sub-dimension. The column chart of the participants who need and do not need training according to each sub-dimensions of the scale is given in Figure 1.

Figure 1

Training Needs Chart of the Participants According to Each Sub-dimensions

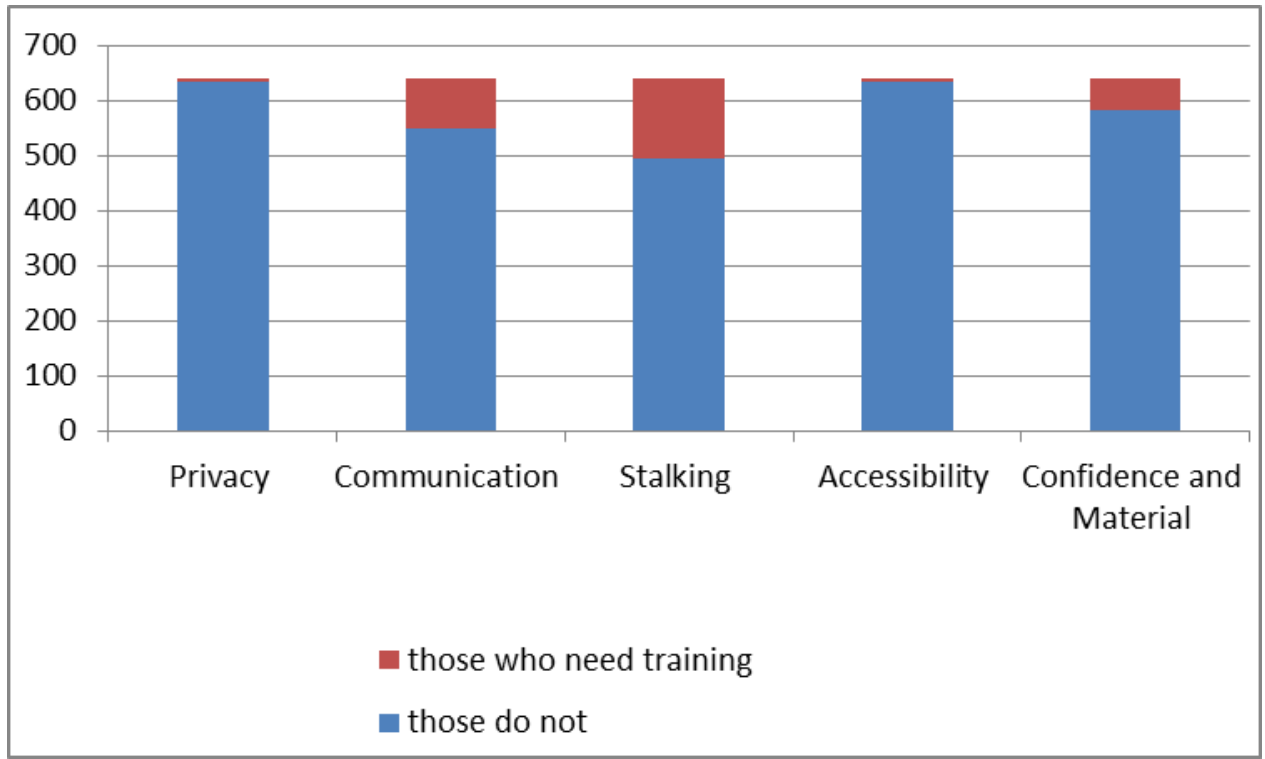

According to Figure 1, the area shown with the blue bar represents those who do not need training, and the area shown with the red bar represents those who need training. The sum of the two bars gives the number of participants, 641. As seen in the figure, training is required mostly in the third, second, fifth, fourth, and first subdimensions, respectively. 


\section{Teachers' Training Needs according to their Gender}

The results of the Mann Whitney-U test, in which sub-dimensions are compared according to gender, are given in Table 7.

Table 7

$M-W U$ Test Result of Ethical Use of IT in Education According to Gender

\begin{tabular}{ccccccc}
\hline Gender & $n$ & Mean Rank & $\begin{array}{c}\text { Sum of } \\
\text { Ranks }\end{array}$ & $M-W U$ & $p$ & $\begin{array}{c}\text { Significance } \\
\text { Effect Size }\end{array}$ \\
\hline Female & 356 & 331.69 & 118081.00 & $46925.00^{*}$ & $.031 *$ & $\begin{array}{c}p<.05 \text { Yes } \\
\text { Cohen-d }=.129\end{array}$ \\
Male & 285 & 307.65 & 87680.00 & &
\end{tabular}

* for 4. factor Accessibility

When the mean scores of the teachers regarding the sub-dimensions of the scale were evaluated, there was no significant difference in terms of gender in the factors other than the 4th factor $(U=46925.00, p<.05)$. The effect size of the difference between male and female teachers was Cohen-d=.129. It could be said that the effect value was too small to be ignored. Considering their mean rank, it was that female teachers have used information technologies more ethically than men.

The Cohen $\mathrm{d}$ value calculated for the Mann Whitney-U test indicates a large effect if it is above .8, medium effect if it is above .5 , and small effect size if it is above .2. For the Kruskal-Wallis test, if it is above .4, it indicates a large effect, if it is above .25 , it indicates a medium effect, and if it is above .1, it indicates a small effect size (Büyüköztürk, 2012, p. 44; Şevgin \& Çetin, 2017).

\section{Teachers' Training Needs according to their Teaching Level}

Kruskal-Wallis test results of ethical use of IT in education according to teaching levels are given in Table 8.

Table 8

Kruskal-Wallis Test Results of Ethical Use of IT in Education According to Teaching Levels

\begin{tabular}{lccccccc}
\hline & $\begin{array}{c}\text { Teaching } \\
\text { Level }\end{array}$ & $n$ & $\begin{array}{c}\text { Mean } \\
\text { Rank }\end{array}$ & $s d$ & $\chi^{2}$ & $p$ & $\begin{array}{c}\text { Significance } \\
\text { Effect Size }\end{array}$ \\
& Primary & 235 & 295.76 & & & & $\begin{array}{c}\text { p<.05 Yes } \\
\text { 3.Factor }\end{array}$ \\
Stalking & Secondary & 250 & 319.05 & 2 & 12.835 & $.002 *$ & $\begin{array}{c}\text { Primary-High S. } \\
\text { High School }\end{array}$ \\
& 156 & 362.15 & & & & $\begin{array}{c}\text { Secondary-High S. } \\
\text { Cohen-d=.263 }\end{array}$ \\
& Primary & 235 & 319.01 & & & & $p<.05$ Yes \\
4.Factor & Secondary & 250 & 307.41 & 2 & 7.293 & $.026^{*}$ & $\begin{array}{c}\text { Secondary-High S. } \\
\text { Cohen-d=.183 }\end{array}$ \\
\hline
\end{tabular}


When the mean scores of the teachers regarding the sub-dimensions of the scale were evaluated, there was no significant difference in terms of teaching level in factors other than the 3rd factor $\left(\chi^{2}(d f=2, n=641)=12.83, p<.05\right)$ and 4 th factor $\left(\chi^{2}(d f=2\right.$, $n=641)=7.29, p<.05)$. The effect size of the difference between the levels in the third factor was Cohen-d=.263. It could be said that the value had a medium effect size. The effect size of the difference between the levels in the fourth factor was Cohen- $d=.183$. It could be said that the value had a small effect size.

Mann Whitney-U test was conducted in order to determine in which levels there was a significant difference. According to the $U$ test results of the third factor, significant differences were found between primary and high school teachers $(U=14535.50, p<.05)$ and between secondary and high school teachers $(U=16875.00$, $p<.05)$. According to the $\mathrm{U}$ test results of the fourth factor, significant differences were found between secondary and high school teachers $(U=17160,50, p<.05)$. Considering the mean rank of the groups for the third factor, it was seen that the most ethical level was high school, middle school, and primary school, respectively. Considering the mean rank of the groups for the fourth factor, it was seen that the most ethical level was high school, primary school and secondary school, respectively.

\section{Teachers' Training Needs according to their Professional Seniority}

Kruskal-Wallis test results of ethical use of IT in education according to professional seniority are given in Table 9 .

Table 9

Kruskal-Wallis Test Results of Ethical Use of IT in Education According to Professional Seniority

\begin{tabular}{|c|c|c|c|c|c|c|c|}
\hline & $\begin{array}{c}\text { Professional } \\
\text { Seniority }\end{array}$ & $n$ & $\begin{array}{l}\text { Mean } \\
\text { Rank }\end{array}$ & $s d$ & $\chi^{2}$ & $p$ & $\begin{array}{l}\text { Significance } \\
\text { Effect Size }\end{array}$ \\
\hline \multirow{6}{*}{$\begin{array}{l}\text { 1.Factor } \\
\text { Privacy }\end{array}$} & $0-5$ & 81 & 273.08 & \multirow{6}{*}{4} & \multirow{6}{*}{14.846} & \multirow{6}{*}{$.005 *$} & $p<.05$ Yes \\
\hline & $6-10$ & 160 & 319.61 & & & & $0-5 / 6-10$ \\
\hline & $11-15$ & 143 & 335.18 & & & & $0-5 / 11-15$ \\
\hline & 16-16 & 124 & 35865 & & & & $0-5 / 16-20$ \\
\hline & & & & & & & $6-10 / 16-20$ \\
\hline & $21++$ & 133 & 301.50 & & & & $\begin{array}{c}16-20 / 21++ \\
\text { Cohen-d=.263 }\end{array}$ \\
\hline \multirow{5}{*}{$\begin{array}{c}\text { 5.Factor } \\
\text { Confidence } \\
\text { and Material }\end{array}$} & $0-5$ & 81 & 302.16 & \multirow{5}{*}{4} & \multirow{5}{*}{12.760} & \multirow{5}{*}{$.013 *$} & \multirow{5}{*}{$\begin{array}{c}p<.05 \text { Yes } \\
6-10 / 21++ \\
11-15 / 21++ \\
16-20 / 21++ \\
\text { Cohen-d=.236 }\end{array}$} \\
\hline & $6-10$ & 160 & 335.33 & & & & \\
\hline & $11-15$ & 143 & 329.79 & & & & \\
\hline & $16-20$ & 124 & 350.63 & & & & \\
\hline & $21++$ & 133 & 278.15 & & & & \\
\hline
\end{tabular}

When the mean scores of the teachers regarding the sub-dimensions of the scale were evaluated, there was no significant difference in terms of professional seniority in factors other than the 1 st factor $\left(\chi^{2}(s d=4, n=641)=14.84, p<.05\right)$ and 5 th $\left(\chi^{2}(s d=4\right.$, $n=641)=12.76, p<.05)$. The effect size of the difference between the levels in the 1 st 
factor was Cohen-d=.263. It could be said that the value had a medium effect size. The effect size of the difference between the levels in the 4th factor was Cohen-d=.236. It could be said that the value has a small effect size.

Mann Whitney-U test was conducted in order to determine in which levels there is a significant difference. According to the $U$ test results of the $1^{\text {st }}$ factor, significant differences were found between the teachers working for 0-5 years and those working for 6-10 years $(U=5505.50, p<.05)$; between the teachers working for $0-5$ years and those working for $11-15$ years $(U=4600.00, p<.05)$; between the teachers working for 0 5 years and those working for $16-20$ years $(U=3713.00, p<.05)$; between the teachers working for 6-10 years and those working for $16-20$ years $(U=8675.00, p<.05)$ and between the teachers working for 16-20 years and those working for 21++ years $(U=6852.50, p<.05)$. According to the $U$ test results of the 5th factor, significant differences were found between the teachers working for 6-10 years and those working for $21++$ years $(U=8748.50, p<.05)$; between teachers working for $11-15$ years and those working for $21++$ years $(U=7973.50, p<.05)$; between the teachers working for $16-20$ years and those working for $21++$ years $(U=6479.00, p<.05)$. Considering the mean rank of the groups, it was seen that the most ethical group was the seniority of "16-20", "11-15", "6-10", "21++", and "0-5" respectively for the 1 st factor; and "1620 ", “6-10", " $11-15 "$, " $0-5$ ", and " $21++$ " respectively for the 5 th factor.

\section{Teachers' Training Needs according to their Branch}

Kruskal-Wallis test results of ethical use of IT in education according to main branch are given in Table 10.

Table 10

Kruskal-Wallis Test Results of Ethical Use of IT in Education According to Main Branch

\begin{tabular}{|c|c|c|c|c|c|c|c|}
\hline & $\begin{array}{l}\text { Professional } \\
\text { Seniority }\end{array}$ & $n$ & $\begin{array}{l}\text { Mean } \\
\text { Rank }\end{array}$ & $s d$ & $\chi^{2}$ & $p$ & $\begin{array}{l}\text { Significance } \\
\text { Effect Size }\end{array}$ \\
\hline \multirow{5}{*}{ 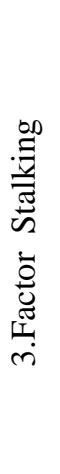 } & Elementary & 230 & 292.55 & \multirow{5}{*}{4} & \multirow{5}{*}{14.222} & \multirow{5}{*}{$.007 *$} & $p<.05 \mathrm{Yes}$ \\
\hline & $\begin{array}{l}\text { Science \& } \\
\text { Math }\end{array}$ & 108 & 337.67 & & & & $\begin{array}{l}\text { Elementary/Science \& } \\
\text { Math }\end{array}$ \\
\hline & $\begin{array}{c}\text { Social } \\
\text { Science \& } \\
\text { Language }\end{array}$ & 188 & 346.56 & & & & $\begin{array}{l}\text { Elementary/Social Science } \\
\text { \& Language } \\
\text { Elementary/Vocational }\end{array}$ \\
\hline & Fine Arts & 49 & 282.88 & & & & $\begin{array}{r}\text { Social Science \& } \\
\text { Language/Fine Arts }\end{array}$ \\
\hline & Vocational & 66 & 348.36 & & & & Cohen- $d=.256$ \\
\hline
\end{tabular}

When the mean scores of the teachers regarding the sub-dimensions of the scale were evaluated, there was no significant difference in terms of main branch in factors other than the 3 rd factor $\left(\chi^{2}(s d=4, n=641)=14.222, p<.05\right)$. The effect size of the difference between the levels in the 3 rd factor was Cohen- $d=.256$. It could be said that the value had a medium effect size. 
Mann Whitney-U test was conducted in order to determine in which branches there was a significant difference. According to the $U$ test results of the 3rd factor, significant differences were found between Elementary and Science \& Math branch teachers $(U=10699.00, p<.05)$; between Elementary and Social Sciences \& Language branch teachers $(U=17921.00, p<.05)$; between Elementary and Vocational branch teachers $(U=6275.000, p<.05)$; between Social Sciences \& Language and Fine Arts branch teachers $(U=3694.50, p<.05)$. Considering the mean rank of the groups for the 3rd factor, it was seen that the most ethical group was Vocational, Social Sciences \& Language, Science \& Math, Elementary, and Fine Arts teachers, respectively.

\section{Teachers' Training Needs according to their Educational Degree}

When the mean scores of the teachers regarding the sub-dimensions of the scale are evaluated, no significant difference was observed in terms of educational degree in these factors.

\section{Discussion and Conclusion}

The main purpose of this research was to determine the training needs of teachers regarding the ethical use of information technologies. The participants were teachers working in public schools in Afyonkarahisar province.

According to the results, $22.8 \%$ of the teachers needed ethical training in the sub-dimension of Stalking, $14.5 \%$ in Communication, 9.4\% in Confidence and Material, $1.1 \%$ in Accessibility, and $1 \%$ in Privacy. According to the results of this study, the average of the training needs of teachers was 9.8\%. In other words, $90.2 \%$ of the teachers did not need training. This result was amazing and higher than expected. According to Ottekin-Demirbolat and Aslan (2014), teachers' ethical sensitivity is at a high level. According to Baydar (2021), school administrators and teachers' perceptions of ethical behaviors were very high.

There was a significant difference between males and females in fourth factor (Accessibility) on the behalf of females. They were more ethical than males. Considering the mean rank, it was observed that female teachers also behaved more ethically than men in first (Privacy) and fifth (Confidence and Material) factors of the scale. These results are similar to the study of Sarıkoç (2018). Males showed more unethical behavior than others. Koçyiğit (2017) also stated that women are more sensitive than men about ethical attitudes in some sub-dimensions or total scores. McCarthy et al. (2005), Roberts et al. (2005), and Adam and Ofori-Amanfo (2000) also figured out that women display more ethical attitudes than men.

In the third factor (Stalking) of the scale, high school teachers showed a significantly more ethical use than primary and secondary school teachers. In the fourth factor (Accessibility), high school teachers behaved significantly more ethically than secondary school teachers. Considering their mean rank, high school teachers were the group that displayed the most ethical behavior in the third, fourth, and fifth (Confidence and Material) factors.

Teachers are classified according to five-year tenure periods. According to the results, it was determined that there was a significant difference between the tenure periods in the first and fifth factors. In the first factor (Privacy), teachers who worked for the first five years showed more unethical behavior than others. In the fifth factor 
(Confidence and Material), teachers who worked for the fifth five years and more show more unethical behavior than others. Sarkoç (2018) also resulted out that elders and those with more years of service show more unethical behavior than others. It has been figured out that teachers who worked for 11-15 years are more sensitive than teachers who worked for 26 years or more (Koçyiğit, 2017). This is the same result; the elder ones behave more unethical behavior.

According to the results, it was figured out that there was a significant difference between main branches in the third factor, namely Stalking. Elementary main branch teachers behaved significantly unethical than other branch teachers. This situation coincides with Roberts et al.'s (2005) study. He stated that different clinicians identified different ethical training needs. Priorities, ethical requirements, and violability have changed as the branches differ.

When the average scores of the teachers regarding the sub-dimensions of the scale are evaluated, no significant difference was observed in terms of education degree in any factor. These findings mean that education degree does not make a significant difference in teachers' ethical use of information technologies in the Privacy, Communication, Stalking, Accessibility, and Confidence \& Material sub-dimensions of the scale.

Calluzzo and Cante (2004) found that the participants did not commit ethical violations regarding Privacy and could commit ethical violations regarding Confidence and Material. This is based on the idea that they could use the property of the institution as they wish. These results coincide with the results of this study. Privacy is the least needed for training among other factors. The Confidence and Material factor is a subject area that requires training for teachers.

It is possible to find the sub-dimensions of Privacy, Integrity, Intellectual Property, Accessibility, Social Impact, Safety, and Quality in ethical scales developed in the context of informatics (Dikbaş-Torun, 2014; Mason, 1986; Namlu \& Odabasi, 2007). The scale used in this research has sub-dimensions named Communication and Stalking in addition to Privacy, Accessibility, Confidence and Material.

\section{Implications for Teachers}

Here, some advice for teachers. They should not secretly pursue their colleagues, students and administrators on social media. Teachers are advised not to talk about extracurricular matters with their students. Teachers should avoid behaviors that will contaminate their corporate identities. Teachers should use technological facilities such as the internet, interactive board, tablet, copier, messaging infrastructure and software for educational purposes, not for providing self-interests. The advice offered to teachers is also recommended for administrators, parents, and students.

\section{Implications for Researchers}

This research was carried out for teachers within the province of Afyonkarahisar. Same kind of a research may be carried out for administrators, parents or students. The validity of this study can be tested with studies to be conducted in other provinces. Training needs of teachers were examined via obtaining their own thoughts. In a new research, their training needs may be examined via obtaining administrators, parents, and students thoughts. 


\section{Conflicts of Interest}

There are no conflicts of interest in this study.

\section{Statement of Responsibility}

Emre Baysan is the most responsible for writing and finalizing the paper. Şaban Çetin is the supervisor. During the review process, all authors revised the paper.

\section{References}

Adam, A., \& Ofori-Amanfo, J. (2000). Does gender matter in computer ethics?. Ethics and Information Technology, 2, 37-47. https://doi.org/10.1023/A:1010012313068

Afyon MEM. (2019). Afyonkarahisar il milli eğitim müdürlüğü [Afyonkarahisar Provincial National Education Directorate]. Retrieved from https://afyon.meb.gov.tr/

Akçadağ, T. (2010). Öğretmenlerin ilköğretim programındaki yöntem teknik ölçme ve değerlendirme konularına ilişkin eğitim ihtiyaçları. Bilig, 53, 29-50.

Akcay, B. (2008). The relationship between technology and ethics; From society to schools. Turkish Online Journal of Distance Education-Tojde, 9(4), 120-127.

Baydar, F. (2021). Relationship between cyberloafing and ethical behaviors: Comparative analysis of teachers and school administrators [Unpublished master's thesis]. Istanbul Sabahattin Zaim University, Graduate Education Institute.

Baysan, E., \& Çetin, Ş. (2019). Eğitimde bilişim teknolojilerinin etik kullanımı ölçeğinin geliştirilmesi çalışması. Türk Eğitim Bilimleri Dergisi, 17(2), 394-417.

Buckinghan, W. (2012). Felsefe kitabı [The philosophy book]. (E. Lakşe, Çev.). İstanbul: Alfa Kitap.

Burton, J. K., \& Merrill, P. F. (1991). Needs assessment: Goals, needs, and priorities. In L. J. Briggs, K. L. Gustafson \& M. H. Tillman (Ed.), Instructional Design Principles and Applications (pp. 17-44). New Jersey: ETP.

Büyüköztürk, Ş. (2012). Sosyal bilimler için veri analizi el kitabı [Manual of data analysis for social sciences]. Ankara: Pegem Akademi.

Calluzzo, V. J., \& Cante, C. J. (2004). Ethics in information technology and software use. Journal of Business Ethics, 51, 301-312.

Can, A. (2016). SPSS ile nicel veri analizi [Quantitative data analysis with SPSS]. Ankara: Pegem Akademi.

Çelen, F. K., \& Seferoğlu, S. S. (2016). Bilgi ve iletişim teknolojilerinin kullanımı ve etik olmayan davranışlar: sorunlar, araştırmalar ve değerlendirmeler. Journal of Computer and Education Research, 4(8), 124-153.

Çetin, Ş. (1997). Ankara ili merkez ilçelerindeki halk eğitim merkezlerinde görevli ĕgitici personelin (öğretmenlerin) yetişkin ĕgitimcisi olarak ĕgitim ihtiyaçlarının saptanması [Unpublished master's thesis]. Gazi University, Graduate School of Educational Sciences.

Cevizci, A. (2012). Etiğge giriş [Introduction to ethics]. İstanbul: Paradigma Yayınları.

Çiftçi, E. (2009). Isşitme engelli öğrenciler için hazırlanan bilgisayar destekli yazılı anlatım becerisi geliştirme materyalinin tasarımi, uygulanması ve 
değerlendirilmesi [Unpublished master's thesis]. Karadeniz Teknik University, Graduate Institute of Natural and Applied Sciences.

Council of Higher Education [CoHE]. (2018). Öğretmen yetiştirme lisans programlart. Ankara: YÖK.

Çörez, A. B. (2016). Öğretim teknolojileri ve etik. In K. Çağıltay \& Y. Göktaş. (Eds.), Öğretim teknolojilerinin temelleri teoriler, araştırmalar, ĕgilimler (pp. 437-453). Ankara: Pegem Akademi.

Creswell, J. W. (2017). Araştırma deseni [Research design]. (S. B. Demir, Çev.). Ankara: Eğiten Kitap.

Cruickshank, D. R., \& Kennedy, J. J. (1976). Research in teacher education: assessing inservice training needs through teacher responses. The Journal of Teacher Education, 27(2), 169-173.

Dedeoğlu, G. (2006, Ekim). Bilişim toplumunda etik sorunlar. Paper presented in II. Uygulamalı Etik Kongresi, ODTÜ-METU, ANKARA.

Demirel, Ö., \& Kaya, Z. (2015). Eğitim bilimine giriş [Introduction to education science]. Ankara: Pegem Akademi.

Dikbaş-Torun, E. (2014). Bilgi ve iletişim teknolojileri kullanımında etik olmayan davranışların modellenmesi. Erciyes İletişim Dergisi, 3(3), 56-70. https://doi.org/10.17680/akademia.v3i3.1005000207

Fidan, M. (2016). Bilişim etiği boyutlarına göre bilişim teknolojileri ve yazılım dersi öğretim programı kazanımlarının incelenmesi. Kastamonu Eğitim Dergisi, 24(4), 1641-1654.

Fraenkel, J., Wallen, N., \& Hyun, H. (2012). How to design and evaluate research in education. New York: McGraw-Hill.

Hu, B. Y. (2010). Training needs for implementing early childhood inclusion in China. International Journal of Early Childhood Special Education, 2(1), 12-30.

Koçyiğit, M. (2017). Öğretmenlik mesleğine ilişkin etik kodlar (Unpublished doctoral dissertation). Osmangazi University, Institute of Education.

Kozma, R. B. (2003). Technology and classroom practice: an international study. Journal of Research on Technology in Education, 36(1), 1-14.

Levent, F., \& Kınık, F. Ş. F. (2017). Türkiye'de eğitim-öğretim alanında etik konulu yapılan lisansüstü tezlerin incelenmesi. Işs Ahlakı Dergisi, 10(1), 99-114.

Leymun, Ş. O. (2018). Bilişim etiği dersinin incelenmesi: Öğretmen adayları ile bir durum çalışması (Unpublished doctoral dissertation). Anadolu University, Graduate School of Educational Sciences.

Mason, R. O. (1986). Four ethical issues of information age. MIS Quarterly, 10(1), 511. https://doi.org/10.2307/248873

Mâta, L., Clipa, O., \& Tzafilkou, K. (2020). The development and validation of a scale to measure university teachers' attitude towards ethical use of information technology for a sustainable education. Sustainability, 12, 6268, 1-19. https://doi.org/10.3390/su12156268 
Mccannon, M., \& Crews, T. B. (2000). Assessing the technology training needs of elementary school teachers. Journal of Technology and Teacher Education, 8(2), 111-121.

McCarthy, R. V., Halawi, L., \& Aronson, J. E. (2005). Information technology ethics: a research framework. Issues in Information Systems, 6(2), 64-69.

Mcee. (2020). Model code of ethics for educators. Retrieved from https://www.nasdtec.net/page/MCEE_Doc

Ministry of National Education [MoNE]. (2014). 19. Millî eğitim şûrası sona erdi $\left(19^{\text {th }}\right.$ National Education Consultation has ended). Retrieved from http://www.meb.gov.tr/19-mill-egitim-srasi-sona-erdi/haber/7594/tr

Ministry of National Education [MoNE]. (2018a). Bilişim teknolojileri ve yazılım dersi ögretim programı. (Information technologies and software course curriculum). Retrieved from http://mufredat.meb.gov.tr/Programlar.aspx

Ministry of National Education [MoNE]. (2018b). Bilgisayar bilimi dersi öğretim programi. (Computer science course curriculum). Retrieved from http://mufredat.meb.gov.tr/Programlar.aspx

Moffat, D. (2013). Clark and kozma debate is it still relevant. Retrieved from https://dcmoffat71.wordpress.com/2013/04/17/clark-and-kozma-debate-is-it-stillrelevant/

Muir, S. T., \& Reeder, W. G. (1929). Code of ethics of the national education association of the united states. Phi Delta Kappa International, 12(3), 69-71.

Namlu, A. G., \& Odabasi, F. H. (2007). Unethical computer using behavior scale: A study of reliability and validity on Turkish university students. Computers \& Education, 48(2), 205-215. https://doi.org/10.1016/j.compedu.2004.12.006

Novella-García, C., \& Cloquell-Lozano, A. (2021). The ethical dimension of digital competence in teacher training. Education and Information Technologies, 26, 35293541. https://doi.org/10.1007/s10639-021-10436-z

Ottekin-Demirbolat, A., \& Aslan, H. (2014). İlk ve ortaokul öğretmenlerinin etik duyarlılıklarının çeşitli değişkenler açısından incelenmesi (Sinop İli Örneği). Ĕğitim Bilimleri Araştırmaları Dergisi, 4(1), 187-206.

Roberts, L. W., Warner, T. D., Hammond, K. A. G., Geppert, C. M. A., \& Heinrich, T. (2005). Becoming a good doctor: perceived need for ethics training focused on practical and professional development topics. Academic Psychiatry, 29(3), 301309. https://doi.org/10.1176/appi.ap.29.3.301

Sarıkoç, Z. (2018). Öğretmenlerin etik olmayan bilgisayar kullanım davranışları ile bilgisayar öz yeterlik alglları arasındaki ilişkinin incelenmesi (Unpublished master's thesis). Ankara University, Graduate School of Educational Science.

Şevgin, H., \& Çetin, B. (2017). Eğitim araştırmalarında güç analizi ve bir uygulama. YYÜ Ĕ̈itim Fakültesi Dergisi, 14(1), 1462-1480.

Sivin, J. P., \& Bialo, E. R. (1992). Ethical use of information technologies in education: important issues for America's schools. Institute for Law and Justice, Inc., Alexandria, VA. 
Stufflebeam, D. L., McCormick, C. H., Brinkerhoff, R. O., \& Nelson, C. O. (1985). Conducting educational needs assessments. USA: KN Publishing.

Tanrıkulu, İ. (2019). How do school children learn cyberbullying perpetration? Journal of Theoretical Educational Science, 12(1), 16-27. https://doi.org/10.30831/akukeg.512556

Taymaz, A. H. (1997). Hizmetiçi ĕgitim: Kavramlar ilkeler ve yöntemler. Ankara: Takav.

TBD. (2010). Türkiye bilişim derneği kamu bilgi işlem merkezleri yöneticileri birliği. Kamu Bilişim Platformu XIII: Bilişim Etiği Nihai Raporu. Retrieved from https://eski.tbd.org.tr/usr_img/kamu_bib/CG2\%20Rapor-28.04.2011.pdf

TDK-BT. (2020). Türk dil kurumu içinde. Retrieved from https://sozluk.gov.tr/

TDK-i. (2020). Türk dil kurumu içinde. Retrieved from https://sozluk.gov.tr/

Vladimirovna, C. E., Igorevna, B. I., Nikolaevna, M. I., Nikolaevna, Z. N., Gennad'evich, T. E., \& Nikolaevna, C. G. (2016). Teachers' training for prevention of pupils' deviant behaviour in ICT. Information Technologies in Science, Management, Social Sphere and Medicine (ITSMSSM). 294-297.

Witkin, B. R., \& Altschuld, J. W. (1995). Planning and conducting needs assessments: A practical guide. Thousand Oaks, CA. Sage Publications.

Yeaman, A. R. J., Eastmond, J. N., \& Napper, V. S. (2008). Professional ethics and educational technology. In A. Januszewski \& M. Molenda (Eds.) Educational technology: A definition with commentary (pp. 283-326). New York: Lawrence Erlbaum Associates/Taylor \& Francis Group. 